Jurnal Psikologi Teori dan Terapan

2017, Vol. 7, No. 2, 88-102 , ISSN: 2087-1708

\title{
Penggunaan Kata "Jancuk" Sebagai Ekspresi Budaya dalam Perilaku Komunikasi Arek di Kampung Kota Surabaya
}

\author{
Sugeng Sriyanto ${ }^{1}$ dan Akhmad Fauzie ${ }^{2}$ \\ (1) Fakultas Psikologi Universitas 17 Agustus 1945 Surabaya \\ ${ }^{(2)}$ Fakultas Psikologi Universitas Hang Tuah, Surabaya
}

\begin{abstract}
The term "jancuk" is part of the dialect of Surabaya people. For Surabaya people known as "Arek Suroboyo" who lives in the neighborhood of kampung kota (the urban village), "jancuk" is the most common word that is used as an expressive language in daily life. However for some people, the word "jancuk" has a negative connotation. This ethnographic study explore how "jancuk" is used and understood by people living in kampung Surabaya who use it as daily communication. Data collected using in-depth interviews and analyzed using three stages of analysis technique suggested by Miles and Huberman: reduction, display, and verification. The result shows that the use of "jancuk" is the common expression in communication which is used because the influence of the social character and the strong internalization of "Arek" culture. "Arek" culture is characterized by its spontaneous, open, and egalitarian values. The use of "jancuk" emphasizes the form of interaction or pragmatic language functions rather than its semantic meaning. In general, the word "jancuk" is used by people who live in urban villages in Surabaya to express their emotion both positive and negative sides. While "jancuk" can be used to express anger, most participants used in friendship circle. People who use the word tend to be viewed as friendly and sociable.
\end{abstract}

Key words: "Jancuk", communication behavior, arek culture, urban villagers

\begin{abstract}
Abstrak: Bagi Arek Suroboyo yang tinggal di lingkungan kampung, kata "jancuk" digunakan sebagai sebagai bentuk ekspresi dalam kehidupan sehari-hari. Peneltian etnografi ini bertujuan untuk mengungkap bagaimana kata "jancuk" dimaknai oleh orang-orang yang menggunakannnya yang tinggal di kampung Surabaya. Data dikumpulkan melalui wawancara secara mendalam dan dianalisis menggunakan teknik reduksi, display, dan verifikasi yang disarankan Miles and Huberman. Hasil analisis menunjukkan penggunaan kata jancuk dalam perilaku komunikasi merupakan ekspresi yang dipengaruhi oleh karakter dan kuatnya internalisasi budaya "Arek". Budaya "Arek" ditandai oleh spontanitas, keterbukaan, dan egalitarianisme. Penggunaan kata jancuk lebih menekankan pada bentuk fungsi interaksi atau prakmatik bahasa dari pada makna semantiknya. Kata ini sering diucapkan oleh orang kampung Surabaya untuk mengekspresikan emosi positif maupun negatif. Menjadi negatif ketika kata ini digunakan sebagai ekspresi kemarahan yang ditujukan pada orang lain. Pada sisi positif dalam sebuah interaksi persahabatan, orang yang menggunakan kata ini dianggap memiliki karakteristik sebagai orang yang ramah dan suka bergaul.
\end{abstract}

Kata Kunci: “Jancuk”, perilaku komunikasi, budaya Arek, komunitas kampung

Korespondensi terkait artikel ini dapat ditujukan kepada Akhmad Fauzie via email: akhfal4@ gmail.com. 
Budaya arek merupakan satu dari sepuluh culture area (wilayah kebudayaan) yang ada di wilayah Provinsi Jawa Timur. Dalam pemahamannya, Akhudiat menjelaskan, arek berasal dari kata lare atau anak-anak. Boedhimoertono (2003:57) menyatakan, kata arek memiliki arti yang luas, tidak hanya digunakan sebagai panggilan untuk anak kecil. Lebih dari itu, kata arek juga digunakan untuk memanggil orang yang sudah mencapai tahapan dewasa dalam tahapan perkembangan. Sedangkan menurut Supriyanto (dalam Abdillah, 2007:2), kata arek berasal dari kata bahasa Jawa Kuno, yaitu ari-ika yang memiliki arti saudara yang lebih muda atau bisa pula anak. Lebih lanjut, dalam kamus Jawa Kuno-Indonesia diartikan sebagai adik laki-laki atau perempuan. Sedangkan dalam penggunaan-nya, kata ari juga dapat digunakan sebagai bentuk sapaan bagi kerabat jauh, bahkan juga bisa digunakan sebagai bentuk sapaan yang bukan kerabat (Zoetmulder, 1995:62). Sedangkan dalam Kamus Pepak Bahasa Jawa, kata ari memiliki arti sebagai benda kawi yang memiliki arti adhi, rayi; ari-ari: aruman, seng metu sakbare mbayi (suatu benda yang keluar setelah orang selesai melahirkan), atau bisa disebut dengan plasenta (latin), embing-embing (Sudaryanto dan Pranomo, 2001:41 dalam Abdillah, 2007:3). Lebih lanjut Henrikus Supriyanto (dalam Abdillah, 2007:3) menegaskan, bahwa ari-ika atau dalam bahasa Jawa Kuno disebut Arika dalam pelafalannya berubah menjadi arek dan menjadi suatu bentuk sapaan baru pada wilayah yang tergabung dalam budaya arek. Sedangkan dalam konteks perkembangannya, Cak Kadar menjelaskan, bahwa kata arek dulunya hanya berlaku bagi anak-anak yang yang tingal di kampung. Akan tetapi dalam perkembangannya, kata arek sudah sedemikian memasyarakat. Sedangkan penyebutan arek tidak mengenal usia, baik untuk balita, anak-anak, anak baru gede (ABG), dewasa, semuanya dapat disebut dengan arek (Mawardi, 2007:23).

Secara geografis, budaya arek terletak dan berkembang di bagian timur aliran Kali Brantas, meliputi Surabaya, Sidoarjo, Gresik, Mojokerto, Jombang, dan Malang. Sedangkan Kediri dan Blitar dibatasi oleh Pare ke timur memiliki khazanah budaya arek (Jawa Pos, Selasa, 30 Oktober 2007: 32). Perjalanan dan perkembangan budaya arek tidak bersifat otomatis dan mekanistik. Wilayah Malang dan Surabaya menjadi pusat perkembangan budaya arek. Sedangkan daerah Gresik dan Sidoarjo masih memiliki identitas budaya arek yang relatif sama dengan Surabaya (Jawa Pos, Selasa, 30 Oktober 2007: 32). Akan tetapi, dalam perjalanan dan perkembangan budaya arek, khususnya mnegenai penggunaan kata arek, begitu melekat pada kata Suroboyo. Sehingga, dalam penyebutannya menjadi arek Suroboyo. Kata arek Suroboyo semakin populer dan mencapai titik puncaknya ketika digunakan pada masa-masa perjuangan kemerdekaan. Dampak dari penggunaan kata arek menjadi arek Suroboyo, kemudian membentuk dan menjadi suatu identitas yang dapat mengintegrasikan para arek Suroboyo untuk melecut dan memperkuat semangat mengusir kolonialisme dan mempertahankan kemerdekaan.

Lebih jauh mengenai budaya arek Suroboyo, memiliki karakteristik tersendiri yang terbentuk dari pengaruh sikap spontanitas yang dimiliki oleh masyarakat antar kampung ketika pada masa perjuangan menuju kemerdekaan (Abdilah, 2007:5). Sikap spontanitas yang dimiliki oleh masyarakat Surabaya, kemudian membentuk karakter khas yang bersifat kultural. Lebih dari itu, bentuk spontanitas tersebut yang juga menciptakan karakter budaya yang terintegrasi dalam kehidupan masyarakatnya (Abdillah, 2007:5). Kadaruslan (dalam Abdillah, 2007:6) menyatakan, bahwa budaya arek Suroboyo memiliki tiga ruang simbolis yang juga 
sekaligus sebagai suatu bentuk aktualisasi, yaitu egaliter, demokratis, dan terbuka.

Berdasar pada ketiga unsur tersebut di atas yang merupakan wujud dari kesinambungan relasi sosial dan kemanusiaan yang terbangun secara spontan (Abdillah, 2007:6). Suatu relasi sosial yang merupakan perwujudan dari karakter arek Suroboyo di atas dapat terbentuk karena adanya unsur interaksi sosial yang tekandung didalamnya. Kegiatan interaksi sosial dapat berjalan karena adanya komunikasi. Agar kegiatan komunikasi dapat terwujud, maka diperlukan suatu alat yang disebut dengan bahasa. Berkaitan dengan budaya arek Suroboyo, pada umumnya, bahasa yang dipergunakan dalam percakapan sehari-hari terbagi menjadi tiga bagian, yaitu: pertama, bahasa formal atau resmi, yakni menggunakan bahasa Indonesia. Kedua, bahasa antar kelompok, merupakan bahasa yang hanya berlaku pada kelompok tertentu saja, seperti bahasa mandarin, bahasa bahasa Madura. Akan tetapi, dalam penggunaannya sangat terbatas. Sedangkan yang ketiga, adalah bahasa Jawa dialek Surabaya atau yang lebih populer disebut dengan basa Suroboyoan (Djupri, 2008:vii). Basa Suroboyoan merupakan bahasa yang dipergunakan dalam pergaulan dan kehidupan sehari-hari oleh seluruh lapisan masyarakat sebagai suatu bentuk keakraban satu dengan lainnya (Abdillah, 2007:130) dalam situasi informal (Djupri, 2008:vii). Hal tersebut dikarenakan, penggunaan basa Suroboyo memiliki kesan psikologis bagi para pengguna bahasa tersebut, yaitu akan lebih akrab, percaya diri dan lebih merasa egaliter (Djupri, 2008:vii).

Lebih jauh mengenai penggunaan bahasa Suroboyoan dalam interaksi sosial dan berkomunikasi oleh arek Suroboyo, khususnya yang berada di kampungkampung Suroboyo, terdapat suatu kata khas yang sering digunakan, yaitu kata jancuk. Menurut Sabrot D. Malioboro, kata jancuk merupakan kata yang apabila dalam penggunaannya menjadi bagian dari bahasa Suroboyoan yang paling komunikatif. Berdasarkan pada asal mula kata cuk merupakan kependekan dari kata jancuk. Diucapakan dengan menggunakan kata cuk agar dapat lebih memudahkan dalam pengucapannya dalam perilaku komunikasi. Sedangkan dalam definisinya kata jancuk dipahami sebagai bahasa yang paling komunikatif dalam mengekspresikan sesuatu. Akan tetapi, ada juga yang mendefinisikan bahwa kata tersebut memiliki arti yang kotor.

Pada umumnya, kata jancuk akan digunakan untuk mengumpat (mesoh). Selain itu, kata jancuk juga identik dengan makian dan dianggap sebagai tantangan untuk berkelahi (Sulistyo, 2009). Kata ini terkenal saru (tidak pantas diucapkan), namun populer di kalangan masyarakat Jawa Timur, khususnya Kota Surabaya dan Malang. Kata ini selalu muncul dalam kondisi sedang marah, kecewa, mengancam, bahkan bisa juga dalam berbagai situasi keakraban, dengan catatan keakraban yang ekstra akrab antar teman dekat (Sulistyo, 2009).

Sebagai bagian dari perilaku komunikasi, khususnya di Kota Surabaya, penggunaan kata jancuk memiliki fungsi dan makna yang bervariasi, tergantung dari situasi dan kondisi dari komunikasi yang dilakukan. Keberagaman fungsi dan makna dari penggunaan kata jancuk dalam perilaku komunikasi masyarakat Kota Surabaya merupakan fenomena budaya lokal yang perlu untuk digali dan dipahami. Pemahaman tentang penggunaan kata jancuk akan mampu memberikan suatu penjelasan secara obyektif bagi individu yang bukan dari Kota Surabaya atau pendatang untuk lebih dapat berperilaku toleran dalam berkomunikasi sehingga tidak terjadi kesalah pahaman.

Berdasarkan pada uraian pada latar belakang masalah di atas dapat ditarik suatu rumusan masalah, yaitu bagaimana penggunaan kata jancuk dalam perilaku komunikasi (communication behavior) 
sebagai ekspresi budaya arek di komunitas kampung Surabaya. Lebih jauh, rumusan masalah tersebut dapat dikembangkan menjadi sub-sub pertanyaan, adalah sebagai berikut: Bagaimana penggunaan kata jancuk dalam perspektif psikolinguistik? Bagaimana dinamika penggunaan kata jancuk dalam perilaku komunikasi?

Perilaku komunikasi (communication behavior) menjadi salah satu fokus kajian dalam disiplin ilmu antropologi, khususnya etnografi komunikasi (communication etnography). Perilaku komunikasi secarra umum didefinisikan sebagai suatu perilaku yang lahir dari tiga integrasi keterampilan yang dimiliki oleh setiap individu sebagai makluk sosial. Ketiga keterampilan tersebut terdiri dari keterampilan linguistik, keterampilan interaksi, dan keterampilan budaya (Kuswarno, 2008:166). Berdasarkan pada pengertian mengenai perilaku komunikasi terseebut, dapat ditarik suatu pemahaman, bahwa perilaku komunikasi menuntut adanya suatu bentuk penguasaan dari beberapa keterampilan dan kompetensi, baik dalam bentuk keteram-pilan linguistik atau bahasa, keterampilan berinteraksi, dan keteram-pilan budaya dalam berperilaku dari seorang penutur (Purwoko, 2008:4).

Perilaku komunikasi dipahami sebagai bentuk intergrasi dari dua kata, yaitu perilaku (behavior) dan komunikasi (communication). Perilaku (Sarwono, 2010:8) atau yang disebut dengan istilah aktivitas (Walgito, 2004:10) dalam definisinya diartikan sebagai bagian dari elemen-elemen stimulus dan respon (Brennan, 2006:356). Kata perilaku juga disepadankan dengan sebutan perbuatan (Sarwono, 2010:8). Perbuatan dibagi menjadi dua macam, perbuatan terbuka (overt) dan tertutup (covert). Perilaku yang terbuka didefinisikan perilaku yang kasat mata, dapat diamati secara langsung melalui pancaindera. Perilaku tertutup diartikan sebagai perilaku yang dapat diketahui secara tidak langsung, seperti berfikir, berkhayal, takut, dan sebagainya
(Sarwono, 2010:8). Sedangkan menurut Woodworth dan Marquiz (dalam Sarwono, 2010:10) perilaku dibagi menjadi tiga bentuk aktivitas, yaitu aktivitas motorik, aktivitas kognitif, dan emosional. Mengacu pada penjelasan mengenai perilaku seperti yang telah dijelaskan di atas dapat dipahami, bahwa perilaku merupakan aktivitas-aktivitas atau perbuatan, baik dalam bentuk tertutup maupun terbuka yang disertai dengan aktivitas kognitif, aktivitas, emosional, dan aktivitas motorik. Sedangkan kata komunikasi, secara umum diartikan sebagai suatu proses penyampaian dan penerimaan lambang-lambang yang mengandung arti, baik dalam bentuk informasi-informasi, pemikiran-pemikiran, pengetahuan ataupun yang lain-lain dari penyampai atau yang disebut dengan komunikator kepada penerima atau komunikan (Walgito, 2003:75). Bertolak pada definisi mengenai komunikasi tersebut dapat dipahami bahwa, komunikasi merupakan suatu bentuk perilaku, dimana terdapat suatu proses aktivitas-aktivitas atau perbuatan berupa penyampaian dan penerimaan lambang-lambang dari komunikator kepada komunikan dalam bentuk aktivitas kognitif, aktivitas emosional, dan aktivitas motorik yang dicirikan dengan penyampaian informasi dan pemikiranpemikiran, berupa ide dan gagasan.

Berdasar pada pemahaman dalam ruang lingkup kajian psikologi, perilaku komunikasi merupakan bagian dari perilaku sosial (social behavior). Pemahaman ini didasarkan, bahwa terben-tuknya perilaku komunikasi pada individu dipahami sebagai fungsi interaksi atas masukan dari situasi sosial dan karakteristik individual. Situasi sosial dalam perspektif ini dipahami sebagai segala sesuatu yang dapat mempengaruhi perilaku individu yang bersifat eksternal dan lebih diartikan sebagai faktor-faktor yang berasal dari luar diri individu atau disebut dengan faktor lingkungan. Faktor lingkungan dalam klasifikasinya dapat dibagi menjadi dua bagian, lingkugan fisik dan lingkungan 
sosial. Lingkungan fisik dalam pengertiannya adalah merupakan segala sesuatu yang berkaitan dengan kondisi alam, misalnya keadaan tanah dan keadaan musim. Perbedaan atas lingkungan fisik tersebut akan memberikan suatu hal yang berbeda pada perkembangan individu. Sedangkan lingkungan sosial dalam definisinya diartikan sebagai lingkungan masyarakat yang didalamnya terdapat adanya interaksi inidividu dengan individu yang lainnya (Walgito, 2003:26-27).

Sedangkan yang dimaksud dengan karakteristik individual adalah segala sesuatu yang bersifat internal yang berasal dari dalam diri individu. Karaktristik individu ini meliputi segala sesuatu yang bersifat internal didalam diri individu sendiri. Karakteristik individual yang dimaksud dapat berupa sifat-sifat fisik, memiliki sifat relatif tetap dan sebagian besar dari sifat-sifat fisik tersebut dapat diketahui oleh orang lain. Karakteristik yang lainnya dari individu dapat berupa karaktristik kepribadian. Karaktristik kepribadian ini memiliki sifat yang cenderung menetap, akan tetapi tidak begitu banyak diketahui oleh individu yang lainya. Selain itu, terdapat juga karakterik yang bersifat internal lainnya dalam diri individu, antara lain berupa sikap, opini, konsep diri, akan tetapi karakteristik ini lebih bersifat temporer, dapat berubah sewaktu-waktu. Individu sering kali dihadapkan dengan berbagai macam pilihan terkait seberapa besar dari wilayah tersebut dapat diperlihatkan kepada orang lain (Bordens \& Horowitz, 2002: 6).

Sebagai hasil interaksi antara karakteristik individual dan masukan dari situasi sosial, kemudian akan membentuk persepsi dan kognisi sosial. Kognisi dan persepsi sosial akan mengarahkan individu dalam melakukan interpretasi dan evaluasi. Interpretasi dan evalusasi yang dilakukan oleh individu akan mempengaruhi kecenderungan perilaku yang akan dilakukan. Sehingga pada akhirnya, individu tersebut akan menampilkan suatu perilaku sebagai bentuk respon dari rangsangan yang berasal dari lingkungan eksternal dan internal, khususnya berupa perilaku komunikasi.

\section{Perilaku Komunikasi dan Perilaku Sosial dalam Kajian Psikologi Budaya}

Salah satu unsur dari dinamika perilaku komunikasi sebagai perilaku sosial adalah berupa masukan situasi sosial. Salah satu bagian dari masukan situasi sosial adalah budaya (culture). Secara umum budaya didefinisikan sebagai seperangkat sikap, nilai, keyakinan, dan perilaku yang dimiliki oleh sekelompok orang, akan tetapi ada tingkat derajat perbedaan pada setiap individu, dan dikomunikasikan dari satu generasi ke generasi berikutnya (Matsumoto, 2008:6). Berdasar pada pengertian mengenai budaya diatas, Matsumoto membagi kebudayaan menjadi dua bentuk konsep, budaya dipahami sebagai konstruk individu dan konstruk sosial. Budaya tidak akan pernah lepas dari pengertian suatu kelompok individu. Dimana setiap kelompok memiliki suatu kekhasan yang membeda-kannya dengan kelompok lainnya. Pada umumnya, suatu kelompok budaya diwilayah tertentu akan memiliki kesamaan dalam karakter kepribadian, perilaku, dan nilai-nilai yang akan menjadi suatu ciri khas dan membedakannya dengan kelompok lainnya. Bentuk pemahaman tersebut disebut dengan budaya dalam arti sosial (Dayakisni, 2004:9). Hal tersebut di atas dapat dicontohkan dalam bentuk perilaku komunikasi sebagai perilaku sosial di komunitas kampung Kota Surabaya, khususnya terkait dengan penggunaan kata jancuk. Di komunitas kampung Kota Surabaya, kata jancuk merupakan kata yang sudah umum digunakan dalam interaksi dan komunikasi, karena kata tersebut diyakini sebagai kata yang paling komunikatif apabila digunakan dalam berinteraksi dan berkomunikasi. Sedangkan pemahaman mengenai budaya dalam 
arti inividual dapat dipahami sejauh mana seorang individu menginternalisasi sikap, nilai, keyakinan, dan perilaku dari kelompok budayanya (Dayakisni, 2004:9). Wujud dari tingkatan internalisasi pada individu dapat dicontohkan dengan perilaku komunikasi sebagai perilaku sosial, terkait dengan penggunaan kata jancuk. Pada individu yang tergabung dalam komunitas kampung Kota Surabaya memiliki berbagi macam sikap, nilai, dan keyakinan terkait penggunaan kata tersebut dalam perilaku komuikasi.

\section{Karakter Budaya Arek}

Budaya Arek terletak di sisi timur Kali Brantas, yaitu mulai dari Kediri dan perbatasan dengan Blitar. Kemudian berlanjut hingga Malang, Jombang, Mojokerto, Sidoarjo, Gresik, dan Surabaya (Abdillah, 2007:108). Sedangkan dalam perkembangannya, budaya Arek tidak lepas dari keberadaan dari komunitas orang kampung (Abdillah, 2007:109). Terkait dengan komunitas orang kampung, terdapat tiga konsep simbolik yang digunakan dalam interaksi sosial seharihari dan tiga kosep simbolik tersebut dipahami sebagai karakter arek Suroboyo, yaitu egaliter yang dipahami dengan arti kerakyatan, demokratis yang diartikan dengan keterbukaan, dan solidaritas (Abdillah, 2007:126). Ketiga konsep tersebut terwujud dalam interaksi sosial sehari-hari terutama ketika masing-masing warga masyarakat berkumpul atau bertemu dalam berbagai bentuk pertemuan. Pada umumnya pertemuan yang paling menonjol terkait dengan ketiga konsep simbolik tersebut diatas adalah cangkrukan. (Abdillah, 2007:126).

\section{Perilaku Komunikasi Budaya Arek}

Perkembangan budaya Arek tidak lepas dari keberadaan dari komunitas orang kampung (Abdillah, 2007:109). Individu yang tergabung dalam komunitas kampung menggunakan berbagai macam bahasa dalam berkomunikasi. Ada berbagai macam bahasa yang digunakan dalam percakapan sehari-hari. Pertama, bahasa formal atau resmi, yaitu dengan menggunakan bahasa Indonesia. Kedua adalah bahasa antar kelompok. Bahasa ini merupakan bahasa yang hanya digunakan dan berlaku pada kelompok tertentu, seperti bahasa Mandarin dan bahasa Madura. Terakhir atau yang ketiga adalah bahasa Jawa dialek Surabaya atau yang disebut dengan boso Suroboyoan (Djupri, 2008:vii). Bahasa ini merupakan bahasa yang dipergunakan dalam pergaulan sehari-hari oleh semua lapisan masyarakat yang tinggal di kampung Surabaya (Abdillah, 2007:130).

\section{Kata Jancuk Dalam Perilaku Komunikasi Budaya Arek}

Menurut Henrikus Supriyanto bahwa kata jancuk berasal dari kata diancuk yang memiliki arti disetubuhi. Jancuk merupakan kata sapaan dan ketika ada seseorang yang disapa jancuk, berarti ibumu disetubuhi oleh ayahku. Jadi kata jancuk memiliki makna ada ikatan persaudaaan antara orang yang menyapa dan yang disapa. Kata jancuk atau penggalan katanya cuk adalah bentuk kata yang digunakan untuk menunjukan rasa keakraban, khususnya yang berdiam di kawasan Surabaya dan Malang. Tetapi, makna istilah jancuk juga berada pada titik batas dengan keakraban. Rasanya bukan arek Suroboyo atau gnaro ngalam kalau ketemu teman tanpa disertai salam, jancuk atau potongannya cuk saja. Sering kali salam itu disertai baku pukul yang cukup bikin sakit. Tanpa mengucapkan salam jancuk pasti bukan teman dekat, karena menyebut istilah ini kepada seseorang yang belum dikenal akan mengundang reaksi negatif. Kata jancuk adalah merupakan kata yang mampu menunjukan kedekatan emosi dan keakraban sepasang sahabat. Selain digunakan sebagai bentuk ekspresi yang menunjukkan rasa keakrab an, kata 
jancuk juga digunakan untuk mengumpat kepada seseorang, dapat juga sebagai sebuah ekspresi rasa kemarahan dari seseorang kepada orang lain yang benarbenar marah (Sulistyo, 2009).

\section{Metode}

Fokus dalam penelitian ini adalah penggunaan kata jancuk dalam perilaku komunikasi sebagai ekspresi budaya Arek pada komunitas kampung di Surabaya.

\section{Subjek}

Teknik untuk menentukan subjek yang digunakan dalam penelitian ini adalah menggunakan criterion sampling. Subjek atau informan yang digunakan dalam penelitian adalah sebagai berikut: ini menggabungkan teknik observasi partisipan dan wawancara mendalam. Jadi, selama melakukan observasi, peneliti juga melakukan interview kepada orang-orang yang ada dilapangan penelitian (Sugiono, 2009:232). Penggabungan teknik untuk mengumpulkan data juga dapat dilakukan sebaliknya. Dalam wawancara etnografi komunikasi dapat berlangsung selama peneliti melakukan observasi partisipan (Kuswarno, 2008). Secara khusus, etnografi komunikasi membagi observasi menjadi dua jenis, yaitu observasi partisipan dan non-partisipan. Sedangkan jenis observasi yang digunakan adalah menggunakan observasi partisipan. Pengumpulan data yang kedua adalah menggunakan metode wawancara. Wawan-

Tabel 1. Informan Penelitian

\begin{tabular}{|c|c|c|c|}
\hline No. & Informan Kunci & Informan Ahli & $\begin{array}{c}\text { Informan Insidential } \\
\text { (man of the street) }\end{array}$ \\
\hline 1. & Penduduk Surabaya & $\begin{array}{l}\text { Ahli dan faham mengenai } \\
\text { budaya surabaya. }\end{array}$ & Penduduk Surabaya \\
\hline \multirow[t]{4}{*}{2.} & $\begin{array}{l}\text { Teridentifikasi } \\
\text { menggunakan bahasa }\end{array}$ & $\begin{array}{l}\text { Mengetahui tentang seluk- } \\
\text { beluk dari bahasa Jawa dialek }\end{array}$ & $\begin{array}{l}\text { Teridentifikasi } \\
\text { menggunakan bahasa }\end{array}$ \\
\hline & Suroboyoan dalam & Surabaya atau boso & Suroboyoan dalam \\
\hline & $\begin{array}{l}\text { kesehariannya, khususnya } \\
\text { menggunakan kata } c u k \\
\text { dalam perilaku }\end{array}$ & $\begin{array}{l}\text { Suroboyoan. (untuk } \\
\text { mengetahuinya dapat } \\
\text { dilakukan dengan cara }\end{array}$ & $\begin{array}{l}\text { kesehariannya, khususnya } \\
\text { menggunakan kata } c u k \\
\text { dalam perilaku }\end{array}$ \\
\hline & $\begin{array}{l}\text { komunikasinya sehari- } \\
\text { hari. }\end{array}$ & $\begin{array}{l}\text { melakukan wawancara } \\
\text { mendalam (indept interview)) }\end{array}$ & komunikasinya sehari-hari. \\
\hline 3. & $\begin{array}{l}\text { Bersedia menjadi subyek } \\
\text { penelitian selama } \\
\text { penelitian berlangsung. }\end{array}$ & $\begin{array}{l}\text { Bersedia menjadi subyek } \\
\text { penelitian selama penelitian } \\
\text { berlangsung. }\end{array}$ & $\begin{array}{l}\text { Bersedia menjadi subyek } \\
\text { penelitian selama } \\
\text { penelitian berlangsung. }\end{array}$ \\
\hline
\end{tabular}

(Sumber: Mantra, 2008)

\section{Teknik pengumpulan data}

Menurut Creswell (dalam Syukur, 1992:277), ada tiga teknik utama pengumpulan data dalam studi etnografi yang juga dapat digunakan dalam metode penelitian etnografi komunikasi, observasi partisipan, wawancara, dan penelaahan dokumen (Kuswarno, 2008). Sedangkan dalam penelitian ini hanya menggunakan dua teknik saja, yaitu observasi dan wawancara.. Akan tetapi, pengumpulan data dalam penelitian cara didefinisikan sebagai pertemuan dua orang untuk bertur kaninformasi dan ide melalui tanya jawab, sehingga dapat dikontruksikan makna dalam suatu topik tertentu (Sugiono, 2009).

\section{Lokasi penelitian}

Lokasi dalam penelitian ini kampung Surabayan. Pemilihan kampung Surabayan sebagai lokasi penelitian ini berdasarkan pada rekomendasi subyek inti (SDM), 
bahwa kampung Surabayan masih memiliki nilai-nilai budaya Arek. Selain itu juga, kampung Surabayan juga merupakan salah satu cagar budaya yang dimiliki oleh Kota Surabaya yang berada di tengah-tengah kota.

\section{Analisa data}

Analisis data merupakan proses mencari dan menyusun secara sistematik data yang diperoleh dari hasil wawancara, catatan lapangan, dokumentasi (Sugiono, 2007:88). Teknik analisa yang digunakan dalam penelitian ini adalah analisis data kualitatif yang mengikuti konsep Miles dan Huberman (dalam Sugiono, 2007: 92). Proses analisa data dilakukan setelah data sudah terkumpul. Data yang telah dikumpulkan kemudian dipilah-pilah sesuai kepentingan atau kebutuhan, kemudian dibuat kategori. Langkah selanjutnya adalah melakukan reduksi data. Reduksi data adalah merangkum, memilih hal-hal yang pokok, memfokuskan pada hal-hal yang penting, dicari tema dan polanya. Setelah melewati tahapan pereduksian ini, dilanjutkan dengan tahap penyajian data (data display). Penyajian data dapat dilakukan dalam bentuk tabel, garafik, phie chart, pictogram, dan sejenisnya. Akan tetapi dalam penelitian ini bentuk penyajian lebih menekankan pada paparan data verbal secara terorganisasir di bawah kategori tema tertentu. Tahap terakhir adalah conclusion atau kesimpulan. Penarikan kesimpulan dilakukan dalam penelitian ini sebagai penegasan atas temuan penelitian.

\section{Hasil dan Pembahasan}

\section{Kapan dan dimana kata jancuk digunakan?}

Penggunaan kata jancuk akan sering dijumpai daerah kampung Suroboyo. Sebab, kata tersebut sering digunakan oleh orang kampung dalam berinteraksi dan berkomunikasi dalam kehidupan mereka sehari-hari. Bagi orang kampung, kata jancuk sudah menjadi bagian dari kehidupan sehari-hari dalam penggunaannya, khususnya dalam menjalin relasi sosial. Oleh karena sudah menjadi bahasa sehari-hari, orang kampung menyebutnya dengan istilah sego jangan atau lalapan jangan. Penggunaan kata jancuk dalam perilaku komunikasi dikehidupan seharihari oleh orang kampung akan terasa lebih kental ketika digunakan dalam interaksi dan komunikasi, terutama ketika masingmasing warga kampung berkumpul atau bertemu dalam berbagai bentuk pertemuan. Salah satu bentuk pertemuan yang paling menonjol di wilayah kampung adalah cangkrukan. Cangkrukan merupakan tradisi pertemuan informal oleh warga kampung yang digunakan untuk menyatakan segala sesuatu peristiwa yang sedang terjadi dan sudah terjadi (Abdillah, 2007:126).

Individu dalam perkembangannya, khususnya dalam berperilaku, selain dipengaruhi oleh faktor endogen atau yang dikenal dengan istilah tempramen (Bigot, dkk., 19950 dalam Walgito, 2002:38) juga dipengaruhi oleh faktor lingkungan dimana individu berada atau bisa disebut dengan faktor eksogen (Walgito: 2002:37). Lebih lanjut, Lewin menjelaskan, bahwa tingkah laku itu bergantung pada fungsi dari lingkungan interaksi oraganisme. Sehingga, lingkungan akan berpengaruh pada tingkah laku dan person atau organisme (Walgito: 2002:10). Situasi sosial dalam bentuk pertemuan cangkrukan memberikan suatu masukan berupa stimulus kepada individu untuk mengucapkan kata jancuk dalam perilaku komunikasi. Cangkrukan merupakan bentuk pertemuan informal yang dilakukan oleh Arek Suroboyo, khususnya yang tinggal di kampung. Berdasarkan hasil penelitian yang didapatkan, cangkrukan berlangsung jauh dari kesan formal. Sehingga kesan akrab akan terlihat dari para peserta pertemuan tersebut. Keakraban dari para peserta yang ikut dalam pertemuan tersebut dari 
berbagai kalangan, mulai remaja, dewasa, sampai tua. Tidak ada rasa canggung yang terlihat, semua saling berinteraksi satu sama lain. Tema-tema yang dibicarakan lebih pada masalah-masalah ringan yang mengundang gelak tawa. ketika disela-sela situasi guyonan tersebut, maka kata jancuk akan terucap dari salah satu peserta. Pada saat kata tersebut diucapkan, suasana bertambah hangat dan akrab.

\section{Siapa Pengguna Kata Jancuk?}

Berdasarkan dari hasil penelitian yang telah dilakukan, bahwa kata jancuk paling sering digunakan oleh orang dewasa, khususnya mereka yang tianggal di wilayah kampung. Penggunaan kata jancuk pada orang dewasa dalam perilaku komunikasi dimaknai bukan sebagai bentuk caci maki, atau sebuah luapan emosi. Akan tetapi, penggunaan kata jancuk pada orang dewasa lebih dimaknai sebagai sebuh ekspresi keakraban, kedekatan, dan persaudaraan. Hal tersebut dipengaruhi oleh sikap dan pandangan hidup pada orang dewasa. Pada orang dewasa mengembangkan suatu pandangan hidup sebagai suatu kesatuan nilai yang integral. Sehingga, orang dewasa akan mampu menempatkan semua kejadian, kebenaran, dan nilai-nilai dalam satu sudut pandang tertentu yang mencakup segalanya (Haditomo, 2006:319). Begitu juga ketika menggunakan kata jancuk dalam perilaku komunikasi. Ketika mengucapkan kata tersebut, individu mampu menempatkan kata jancuk secara tepat, baik terkait dengan waktu, tempat, dan aktivitas ketika kata jancuk digunakan dalam komunikasi.

Kata jancuk dalam penggunaannya juga digunakan oleh remaja. Akan tetapi, penggunan kata jancuk pada remaja dalam perilaku komunikasi lebih pengaruhi oleh kelompok sosialnya. Sebab, perilaku individu ketika masih berusia remaja sangat dipengaruhi oleh kelompok sosialnya. Ketika pada usia remaja akan membentuk suatu kelompok dan melepaskan dirinya dari pengaruh dari orang dewasa (Haditomo, 2006:282). Kelompok sosial dimana individu menjalin relasi sosial akan memberikan suatu pengaruh terhadap perkembangan, khususnya dalam berperilaku komunikasi. Begitu kuatnya pengaruh kelompok sosial terhadap individu, maka individu tersebut akan cenderung mengikuti aturan-aturan yang ada di kelompoknya (Sarwono, 2009:105). Ketika suatu kelompok sosial memiliki suatu aturan, bahwa penggunaan kata jancuk bukanlah sebagai suatu bentuk caci maki atau sebagai umpatan. Maka hal tersebut akan diikuti oleh anggota kelompok tersebut.

Tidak hanya terbatas pada orang dewasa dan remaja, anak-anak juga menggunakan kata jancuk dalam perilaku komunikasi. Akan tetapi, penggunaan kata jancuk pada anak-anak, akan dimaknai berbeda dengan orang dewasa dan remaja. Pada anak-anak, penggunaan kata jancuk dalam perilaku komunikasi bukan dipengaruhi oleh dunia sosialnya. Tetapi, penggunaan kata jancuk pada anak-anak lebih dimaknai sebagai sebuah umpatan dan luapan sakit hati. Hal ini dikarenakan, pada usia anak-anak sangat diengaruhi oleh sifat egosentrisme yang yang dimilikinya. Egosentrisme adalah anak-anak dalam memandang segala sesuatu terpusat pada dirinya sendiri (Haditomo, 2006:114). Selain itu, pada pengggunaan kata jancuk dalam perilaku komunikasi dapat juga dipahami sebagai bentuk peniruan atau belajar model. Belajar model dalam definisinya diartikan sebagai proses menirukan tingkah laku orang lain yang dilihat, dilakukan secara sadar maupun tidak sadar (Haditomo, 2006:123).

Bahasa Jawa dialeg Surabaya atau boso Suroboyoan (Djupri, 2008:vii) merupakan bahasa yang paling sering digunakan dalam kehidupan sehari-hari, khususnya dalam menjalin hubungan relasi sosial pada masyarakat Surabaya, khususnya di komunitas kampung dalam situasi informal (Abdillah, 2007:130). 
Lebih juah, dari penggunaan basa Suroboyoan dalam komunikasi, akan terdapat kesan psikologis yang didapatkan oleh para penuturnya, dimana penuturnya akan merasa lebih akrab, menjadi menjadi lebih percaya diri, dan bersifat egaliter (Djupri, 2008:vii). Pada boso Suroboyoan terdapat satu kata yang menjadi fenomena kata-kata lokal yang digunakan dalam perilaku komunikasi pada masyarakat Surabaya, khususnya di komunitas kampung Surabaya, yaitu kata jancuk. Dalam pemahamnnya, kata jancuk merupakan kata yang apabila dalam penggunaannya menjadi bagaian dari bahasa Suroboyoan yang paling komuni-katif. Oleh karena dimaknai sebagai kata yang paling komunikatif, kata jancuk dapat digunakan untuk menunjukkan rasa keakraban. Akan tetapi, kata ini juga dapat digunakan untuk mengumpat kepada seseorang, dapat juga sebagai sebuah ekspresi rasa kemarahan dari seseorang kepada orang lain yang benar-benar marah.

Kata jancuk pada umumnya dipahami sebagai bahasa yang kasar, khususnya ketika warga kampung menggunakannya dalam perilaku komuni-kasi, bahkan kata tersebut dinterpretasikan sebagai bahasa pisuhan. Pendapat tersebut didasarkan bahwa, secara semantik kata jancuk memiliki makna yang kasar, bahkan diidentikan sebagai sarkasme. Semantik adalah bagian dari bahasa yang mempelajari makna dalam bahasa alami tanpa memperhatikan kontek penggunaan-nya (Dardjowidjojo, 2003:26). Berdasar-kan pada asal mula kata, kata jancuk atau yang lebih sering diucapkan dengan kata $c u k$, berasal dari kata tak-ancuk. Kata tersebut dalam pengertiannya diartikan disetubuhi. Oleh karena memiliki arti yang kotor, dalam ujarannya pengucapannya menjadi jancuk. Terdapat juga pendapat yang menyatakan, jancuk itu berasal dari kata di-ancuk. Kata di-ancuk dalam pengertiannya diartikan dengan disetubuhi.

Di lingkungan kampung, kata jancuk dalam pengguna-annya sudah menjadi bahasa sehari-hari. Sehingga dalam penggunaannya, sudah menjadi suatu hal yang biasa bagi warga kampung. Mungkin bisa menjadi suatu kebutukan, dimana dengan menggunakan kata tersebut dalam perilaku komunikasi, suasana akan menjadi cair, dan percakapan akan menjadi lebih akrab.

Dari proses melihat peristiwa sosial, khususnya terkiat dengan penggunaan kata jancuk dalam perilaku komunikasi tersebut, kemudian individu melakukan proses internalisasi dan analisis. Proses yang berupa internalisasi dan analisis tersebut kemudian akan digunakan individu mempersepsi dunianya atau yang disebut dengan persepsi sosial. Persepsi sosial (social perception) adalah suatu proses yang digunakan oleh individu untuk mengetahui, menginterpretasikan, dan mengevaluasi orang lain, terkait dengan sifat-sifat, kualitas, dan keadaan. Sehingga akan didapatkan suatu gambaran mengenai obyek yang dipersepsi (Aronson, 1975 dalam Walgito, 2003:56). Dari proses persepsi tersebut, akan dijadikan individu dalam memandang dunianya, khususnya mengenai kata jancuk. Sehingga, akan didapatkan berbagai macam arti kata jancuk. Walaupun memiliki banyak arti, pada umumnya kata jancuk ini dipahami sebagai suatu bentuk ekspresi. Ungkapan tersebut cukup tepat. Chomsky (1975: 4) mengatakan bahwa bahasa adalah ekspresi atau, lebih tepatnya, a mirror of mind (cermin pikiran manusia) (Purwaka, 2008).

Sedangkan penggunaan kata jancuk dalam perilaku komunikasi, memperhatikan beberapa hal, antara lain adalah sebagai berikut: intonasi suara, tampilan wajah, dan karakter. Penggunaan intonasi suara dari penggunaan kata jancuk dalam perilaku komunikasi memiliki peranan penting. Intonasi suara yang keluar dari penggunaan kata jancuk menunjukkan emosi yang dikeluarkan atau diekspresikan. Emosi (emotion) dalam pengertiannya diartikan sebagai suatu reaksi yang kompleks, mengandung aktivitas dengan 
derajat yang tinggi dan adanya perubahan dalam kejasmanian serta berkaitan dengan perasaan yang kuat (Walgito, 2010: 222). Emosi merupakan suatu keadaan yang ditimbulkan oleh situasi tertentu (khusus), dan emosi cenderung terjadi dalam kaitannya dengan perilaku yang mengarah (approach) atau menyingkiri (avoidance) terhadap sesuatu, dan perilaku tersebut disertai dengan ekspresi kejasmanian. Sehingga orang lain dapat mengetahui, bahwa seseorang sedang mengalami emosi (Walgito, 2010:229).

Pejelasan tentang emosi di atas dapat memberikan suatu pemahaman, bahwa intonasi dapat berperan sebagai media untuk menyampaikan emosi. Hal tersebut dikarenakan, emosi memiliki kecenderungan diwujudkan dalam bentuk perilaku yang mengarah dan disertai dengan ekspresi kejasmanian. Akan tetapi, terdapat bentuk perilaku yang khas ketika orang kampung dalam berperilaku komunikasi. Secara spesifik, warga kampung, walaupun tidak emosi, apabila berbicara akan terlihat seperti orang yang sedang berteriak-teriak dan nampak seperti orang yang sedang marah atau disebut dengan simulasi (simulation). Ekman dan Friesen (dalam Carlson, 1987) menyatakan, orang yang tidak mengalami emosi, tetapi seolah-olah mengalami emosi dengan menampakkan gejala-gejala kejasmanian (Walgito, 2010: 230). Tampilan wajah juga memberikan signifikasi yang penting dalam penggunaan kata jancuk dalam perilaku komunikasi. Para-bahasa berhubu-ngan dengan bagaimana cara dari suatu isi pesan disampaikan, bukan isi dari pesan (Beck, 1992 dalam Hanurawan, 2010:49). Dalam pemahamannya, para-bahasa mengacu pada aspek nonsemantik suatu kalimat. Para-bahasa dapat berbentuk penekanan suara, nada, volume suara pada saat seseorang mengekspresikan suatu makna. Bahasa tubuh (kinesia) menggambarkan komunikasi non-verbal tentang suatu makna yang disampaikan melalui gerak fisik dan mimik muka (Hanurawan,
2010:49). Penjelasan tersebut cukup memberikan suatu pemahaman, dimana peran mimik muka akan memberikan peneguhan ketika seseorang berkomunikasi. Hal tersebut akan terlihat ketika Arek Suroboyo menggunakan kata jancuk dalam perilaku komunikasi. Selain diikuti dengan intonasi suara yang lantang dan keras, ekspresi wajah juga akan selalu mengikuti katika Arek Suroboyo menggunakan kata jancuk. Ekspresi wajah tersebut bertujuan untuk mengekspresikan suatu makna dari penggunan kata jancuk dari perilaku komunikasi yang telah dilakukan.

Karakter juga memberikan peranan penting seseorang dalam berperilaku, khususnya berperilaku komunikasi. Pemahaman tersebut didasarkan, bahwa perilaku komunikasi dipahami sebagai perilaku sosial dalam bentuk aktivitas penyampaian pesan dari komuni-kator kepada komunikan. Istilah karakter dalam pengertiannya merupakan sebuah sifat yang khas yang dimiliki oleh setiap manusia. Karakter dapat juga dipahami sebagai suatu bentuk sifat yang khas yang dimiliki oleh setiap individu (Suryabrata, 2008:1). Kata karakter dapat juga dikenal dengan istilah karakteristik (Lewin dalam Bordens \& Horowitz, 2002). Karakteristik yang ada pada individu dapat terwujud dalam bentuk sikap, opini, konsep diri dan sebagainya. Karakteristik yang dimiliki tersebut, kemudian akan dapat mempengaruhi individu dalam berperilaku ketika dihadapkan pada situasi sosial. Karakteristik yang dimiliki oleh individu dapat digunakan untuk menjelaskan mengapa Arek Suroboyo menggunakan kata jancuk dalam perilaku komunikasi dikehidupan seharihari.

Secara umum, Arek Suroboyo dikenal memiliki karakteristik sebagai orang yang egaliter, terbuka (demokrasi), dan memiliki solidaritas yang tinggi (Abdillah, 2007). Ketiga unsur karakter tersebut akan terwujud dalam perilaku yang ditampilkan sebagai orang yang blater (suka bergaul), terbuka, tempera- 
mennya tinggi, yang diwujudkan dengan emosinya yang meledak-ledak. Sehingga dalam berperilaku, Arek Suroboyo akan terlihat gampang marah, ekspresif, dan terkesan kasar. Akan tetapi dibalik kesan kasar tersebut, Arek Suroboyo adalah orang yang humoris, santai, tidak gampang tersinggung, dan suka bercanda. Karakteristik yang dimiliki oleh Arek Suroboyo yang diwujudkan dalam perilaku merupakan wujud dari budaya Arek.

Matsumoto (dalam Dayakisni, 2004:10) menyatakan, bahwa budaya dalam pengertiannya dipahami sebagai seperangkat sikap, nilai, keyakinan, dan perilaku yang dimiliki oleh sekelompok orang, akan tetapi memiliki tingkat derajat perbedaan internalisasi pada setiap individu dan dikomunikasikan dari generasi kegenerasi berikutnya. Definisi budaya diatas memberikan suatu pemahaman, bahwa pada hakekatnya budaya merupakan suatu bentuk ide, sikap, nilai, keyakinan, dan keprcayaan yang ada pada setiap individu yang hidup disutau wilayah budaya tertentu (Dayakisni, 2004:11). Penjelasan mengenai budaya di atas akan dapat memberikan suatu gambaran mengenai perilaku komunikasi dengan menggunakan kata jancuk. Adanya derajat internalisasi pada masing-masing individu terhadap nilai-nilai yang ada pada suatu budaya akan dapat menunjukkan perbedaan perilaku yang ditampakkannya. Karakter egaliter, terbuka, dan solidaritas yang melekat pada Arek Suroboyo akan dapat dilihat ketika Arek Suroboyo berperilaku, khususnya ketika berperilaku komunikasi. Arek Suroboyo apabila berbicara terlihat meledak-ledak, ceplasceplos. Selain itu, akan diikuti dengan gestur (tangan, mata, wajah), dan yang paling khas ketika berbicara, khususnya ketika berekspresi akan menimbulkan suatau kesan tidak ada tading aling-alinge (tidak ada sekat yang membatasi). Ikut bermainnya tangan, mata, dan ekspresi wajah ketika berkomunikasi dipahami sebagai bentuk peneguhan dengan apa yang mereka ucapkan. Selain itu, juga agar terlihat lebih mantap dan meyakinkan tentang apa yang mereka komunikasikan.

Perilaku yang ditampakkan tersebut, khususnya ketika berperilaku komunikasi, dipengaruhi tingginya derajat internalisasi pada nilai-nilai budaya Arek yang egaliter, terbuka, dan solidaritas. Sebagai wujud internalisasi terhadap budaya Arek diwujudkan dalam bentuk perilaku komunikasi yang khas, khususnya ketika Arek Suroboyo mengucapkan kata jancuk. Kata jancuk yang diucapkan oleh Arek Suroboyo akan terasa lebih mantab

Selain itu, dalam realitas sosialnya, penggunaan kata jancuk akan diikuti parabahasa dengan nada, penekanan, dan volume suara, seperti keras, lantang, penekannya yang mantab, dan terkesan seperti orang yang berteriak-teriak. Parabahasa berhubungan dengan bagaimana cara dari isi pesan disampaikan. Bahasa tubuh juga mengikuti ketika boso Suroboyoan dipergunakan dalam komunikasi, misalnya raut muka, mata melotot, dan tangan ikut bergerak dengan mantab ketika kata atau kalimat diucapka. Penggunaan dari ketiga hal tersebut yang membuat kesan, bahwa kata jancuk merupakan kata yang dimaknai sebagai bahasa pisuhan dan sarkasme. Akan tetapi apabila ditinjau dari pragmatiknya, bagi masyarakat Surabaya pada umumnya, khususnya bagi mereka yang tinggal di lingkungan kampung, kata ini dibuat sebagai bentuk sapaan, dan dimaknai sebagai suatu bentuk rasa keakraban. Ketika kata jancuk digunakan dalam bentuk sapaan, khususnya ketika orang di sapa dengan menggunakan kata jancuk, hal tersebut diartikan, bahwa Ibumu disetubuhi oleh Bapakku, sehingga kamu adalah saudaraku. Sehingga didapatkan suatu pemahaman, ketika seseorang disapa dengan menggunakan kata jancuk, maka orang tersebut sudah dianggap sebagai saudara. Pragmatik merupakan bagian dari bahasan dari psikolinguistik. Pragmatik dalam pemahamnnya bukanlah salah satu 
komponen dalam bahasa, tetapi lebih berfungsi memberikan perspektif dalam bahasa. Prakmatik merupakan salah satu kajian dari psikolinguistik mempelajari tentang makna dalam interaksi antara seorang penutur dengan penutur yang lainnya.

Berdasarkan deskripsi di atas, khususnya dalam perspektif psikolinguistik, dapat dipahami, bahwa penggunaannya kata jancuk dalam perilaku komunikasi menghiraukan arti semantik, makna dalam bahasa alami. Akan tetapi dalam peng-gunannya, lebih menekankan pada fungsi prakmatik, makna-makna yang terkandung dalam interaksi para penuturnya. Perilaku berbahasa tersebut dipengaruhi oleh karakter budaya Arek Suroboyo. Pada umunya, budaya Arek Suroboyo dikenal memiliki karakter yang egaliter. Sehingga, dengan memiliki karakter yang seperti itu, akan mempengaruhi mereka ketika berperilku, khususnya dalam berperilaku bahasa. Terdapat perilaku yang khas ketika orang Surabaya berbahasa. Dalam berbicara, bahasa yang digunakan tidak ada kromo, tidak ada ngoko, akan tetapi bahasa yang digunakan menggunakan bahasa Suroboyoan. Ada hal yang khas terkait dengan bahasa Suroboyoan, dimana bahasa tersebut merupakan bahasa yang egaliter. Sehingga bahasa tersebut tidak ada tingkatannya. Begitu hal dengan kata jancuk, dalam penggunaannya, kata tersebut dipahami sebagai suatu bentuk represetatif dari karakter Arek Suroboyo yang egaliter. Ketika kata jancuk digunakan dalam perilaku komuniasi, akan dimaknai sebagai bentuk rasa keakraban dan orang yang diajak bicara tersebut sudah diangap saudara. Sebab, kata jancuk itu diartikan sebagai saudara.

\section{Dinamika Penggunaan Kata Jancuk}

Bahasa merupakan sarana dalam berkomunikasi dalam kehidupan budaya manusia. Secara spesifik, bahasa memiliki dua fungsi utama. Pertama, bahasa menyebabkan individu dapat berkomunikasi dengan individu yang lainnya. Sedangkan yang kedua, bahasa dapat membantu individu berkomunikasi dengan dirinya sendiri.

Begitu halnya dengan kata jancuk. Kata tersebut merupakan kata yang menjadi bagian dari boso Suroboyoan. Terdapat berbagai macam perspektif mengenai arti kata jancuk. Akan tetapi pada umumnya, kata jancuk lebih dipahami sebagai sebuah ekspresi dan kata yang paling komunikatif bagi masyarakat Surabaya, khususnya bagi warga kampung.

Sebagai kata yang dimaknai komunikatif, kata jancuk dalam penggunaanya dapat digunakan dalam tegur sapa dengan sesama teman di jalan, khususnya bagi teman akrab yang sudah lama tidak bertemu. Selain itu, kata ini juga digunakan ketika sedang asyik ngobrol. Kata ini biasanya juga digunakan sebagai ekspresi, ketika merasa senang hatinya. Selain sebagai luapan kegembi-raan, kata jancuk ini paling sering digunakan sebagai luapan emosi ketika seseorang sedang marah.

\section{Simpulan}

Bagian ini merupakan simpulan penelitian dan jawaban dari pertanyaan peneitian yang tercantum dalam rumusan. Penggunaan kata jancuk dalam perilaku komunikasi sebagai ekspresi budaya arek pada komunitas kampung Kota Surabaya memiliki karakteristik terkait dengan siapa penggunanya, kapan digunakan, di mana digunakan, dan bagaimana cara penggunannya. Kata jancuk pada umumnya sering digunakan oleh orang dewasa yang memiliki kedekatan atau akrab. Bagi orang dewasa, penggunaan kata jancuk digunakan bukan sebagai bentuk caci maki atau sebagai umpatan. Akan tetapi, penggunaannya lebih pada suatu bentuk keakraban.

Sedangkan pada anak-anak, penggunaan kata jancuk lebih pada bentuk 
ekspresi sakit hati dan sebagai bentuk peniruan dari perilaku orang dewasa. Kemudian, kata jancuk ini akan digunakan dalam situasi yang sangat informal dan jauh dari kesan formal, seperti ngobrol atau cangkrukan. Cara penggunaannya memiliki beberapa ciri-ciri khas, intonasi suara ketika mengucapkan kata jancuk akan terdengar keras dan terlihat seperti orang yang sedang berteriak-teriak. Sehingga dalam pengucapannya akan terdengar mantab. Selain itu, dalam pegucapan kata jancuk akan diikuti dengan ekspresi wajah. Hal tersebut menjadi suatu bentuk peneguhan ketika berekspresi dengan menggunakan kata jancuk.

Penggunaan kata jancuk dalam kajian psikolinguistik tidak memperhatikan arti semantik. Secara semantik kata jancuk memiliki makna yang kasar, bahkan diidentikan sebagai sarkasme. Akan tetapi, dalam penggunaannya lebih menekankan pada fungsi prakmatik bahasa, yaitu merujuk pada makna dalam interaksi antara para penggunanya. Sehingga, akan menimbulkan rasa keakraban diantara penggunanya. Sedangkan dinamika penggunaan kata jancuk dalam perilaku komunikasi dapat digunakan sebagai bentuk sapaan bagi orang yang sudah memiliki hubungan dekat atau akrab. Sebalik, kata ini juga akan bisa digunakan untuk mengungkap dan meluapkan emosi marah. Kata jancuk juga dapat digunakan sebagai bentuk ekspresi kagum dan heran. Bahkan juga bisa digunakan sebagai bentuk ekspresi ketika seorang individu dalam keadaan sendirian.

\section{Daftar Pustaka}

Abdillah, A. (2007). Budaya Arek Suroboyo, Sebuah Kajian Terhadap Awal Eksistensinya Melalui Konteks Perubahan Sosial Komunitas Kampung Surabaya. Surabaya: Universitas Airlangga

Abdulgani, R. (1994). Seratus Hari di Surabaya Yang Menggempar-kan Indonesia. Jakarta: PT Jayakarta Agung Offset.

Akhudiat. (2008). Masuk Kampung-Keluar Kampung. Surabaya: Henk Publika.

Baron \& Birney. (2005). Psikologi Sosial. Jakarta: Erlangga.

Bordens \& Horowitz. (2002). Social Psychology. Second Edition. Laurance Erlboum Associates, Inc., Publishers. Mahwah. New Jersey 07430.

Boedhimoerdono. (2003). Jalan Panjang Menuju Kota Pahlawan. Surabaya: Pusura.
Burhan, B. (2007). Penelitian Kualitatif: Komunikasi, Ekonomi, Kebijakan Publik dan Ilmu Sosial Lainnya. Jakarta: Kencana.

Chaer, A. (2003). Psikolinguistik, Kajian Teoritik. Jakarta: Rineka Cipta.

Creswell. (2002). Educational Research: Planning, Conducting, and Evaluating Quantitative and Qualitative Research. Pearson Prentice Hall.

Dardjowidjojo. (2003). Psikolinguistik: Pengantar Pemahaman Bahasa Manusia. Jakarta: Yayasan Obor Indonesia.

Djupri, M. (2008). Kamus Suroboyoan Indonesia. Surabaya: Henk Publika

Haditono. (2006). Psikologi Perkembangan, Pengantar Dalam Berbagai Bagiannya. Yogyakarta: Gadjah Mada University Press. 
Harujati, P. (2008). Jawa Ngoko Ekspresi Komunikasi Arus Bawah. Jakarta: PT Indeks.

Hanurawan, F. (2010). Psikologi Sosial, Suatau Pengantar. Bandung: PT Remaja Rosdakarya Offset.

Jawa Pos. (2007, 30 Oktober). Menelusuri Jejak Kampung Surabaya. Surabaya.

Kuswarno, E. (2008). Etnografi Komunikasi, Suatu Pengantar dan Contoh Penelitiannya. Bandung: Widya Padjadjaran.

Liliweri, E. (2007). Makna Budaya Dalam Komunikasi Antar Budaya. Yohyakarta: PT Lkis Pelangi Aksara.

Mawardi, A. (2007). Cak Kadar. Surabaya: Henk Publishing.

Poerwandari. E. K. 2001. Pendekatan Kualitatif Unutk Penelitian Manusia. Edisi Revisi. Jakarta: LPSP3 UI.

Salim, A. (2006). Teori Dan Paradikma Penelitian Sosial. Yogyakarta: Tiara Wacana.
Sarwono, S.W. (2010). Pengantar Psikologi Umum. Jakarta: Rajawali Pers.

Sarwono, dkk. 2009. Psikologi Sosial. Jakarta: Salemba Humanika.

Sulistyo, H. (2009). Polisi Janchuk. Jakarta: Pensil 324.

Sugiono. (2007). Metode Penelitian Kuantitatif-Kualitatif Dan $R \& D$. Bandung: Alfabeta.

Suharnan. (2005). Psikologi Kognitif, edisi Revisi. Surabaya: Srikandi

Suryabrata. (2008). Psikologi Kepribadian. Jakarta: PT Raja Grafindo Persada.

Sutarto, A dan Setyo, Y.S. (2004). Pendekatan Kebudayaan Dalam Pembangunan Provinsi Jawa Timur. Jember: Kelompok Peduli Budaya dan Wisata Daerah Jawa Timur bekerja sama dengan Pemerintah Provinsi Jawa Timur.

Walgito. (2002). Pengantar Psikologi Umum. Yogyakarta: Andi Yogyakarata.

Zoetmulder. P.J, dkk. (1995). Kamus Jawa Kuno-Indonesia. Jakarta: Gramedia Pustaka Utama. 